\title{
THE IMAGE OF INDIAN WOMEN AND THEIR CONTRIBUTION TO LITERATURE
}

\author{
Dr. Latha Velavan ${ }^{1}$, Maya P.R ${ }^{2}$ \\ ${ }^{1}$ Associate Professor, Sri Sairam Engineering College, West Tambaram, Chennai . \\ ${ }^{2}$ Assistant Professor, Sri Sairam Engineering College, West Tambaram, Chennai.
}

\begin{abstract}
The paper deals with the ancient Indian women and their contribution to literature during the British period. The role of ordinary women and aristocrat ladies were the same in that period. Both were utilized to fulfill their household duties and to act as a consummate hostess to their men at the table. They were portrayed as a secondary character to men in most of the writings. Women were in general unaware of their fundamental rights due to illiteracy. Cruel rites like Sati and Infanticide were imposed on women by the society and more or less they were just treated as a supporting character to uphold the story. It's only at the end of the Second World War, the Indian women got a new sight and light about the world. It's quite interesting to learn how the ancient women lived and experienced the world around them. Women and Literature are interconnected to one another and their writings added new prospects to English Literature. Earlier, only the work of men were greatly appreciated and won recognition from the readers. But then, the effort of women writers came in to light which created a remarkable aspect in their style and matters they conveyed. They always focused on the language patterns of Indian Literature. It is to be noted that because of their varied style in writing women writers have become very popular among the Indian readers.
\end{abstract}

Key words:

Women, Indian Literature, Evidence, Illiteracy, Infanticide

Article Received: 10 August 2020, Revised: 25 October 2020, Accepted: 18 November 2020

\section{Introduction}

In the study about Indian women, Forbes declared that in the Pre-British records the documents about Indian women's actual lives were fewer in number compared to various prescriptive texts. Though women were often the subject to literary works they were portrayed merely as an object for the development of their writings. The image of women ranged from a political peacekeeper to an anti-beauty. In the old English tradition, women were seen as either dutiful slaves or angelic creatures from heaven. However, during the colonial rule with the advent of western philosophies and movements, the strength of the women characters started being focused slowly and steadily in literature. In the views of many male authors, the images of women are the downfall of men. Marlowe in his Dr. Faustus uses the greatest beauty known in literature as the symbol of sin and evil. Even in William Shakespeare's creations, they were portrayed as a character with temptations, weak and powerless, though he created innumerable intelligent women characters later on. Indian women for long had been encircled in the whirlpool of pain and suffering of orthodox society. Though much has been done to relieve them from the pain, the pace of reformation is still slow. The writings of women slowly liberated the women from their social bond. While talking about the status of women, Ania Loomba (2004) in her Colonialism/ Post Colonialism stated that,

"women and gender are seen as emblematic of culture and nation, they also signify breaks or faultlines within these categories. Women who broke the codes of silence and subservience became the objects of extreme hostility, which, in some cases, succeeded in silencing outspoken women ... The more feminist research recovers and re-interprets the lives of women under colonial rule, the clearer it becomes that women, as individuals and as a potential collectivity, constituted a threat and were thus at least partially the target of earlier patriarchal re-writings of tradition".

In the pre-colonial era, majority of the texts were written by men. They deliberately excluded to find out the condition of women so any possibility to know their condition was ruled out. In fact, women's access to education had been extremely limited until the second half of the nineteenth century. It showed that the lives of Indian women remind scare till the end of Second World War. 
Later, the female author's writings on the status of women helped the women to have access to education. But facing colonizers and the Indian males were very difficult and so their education became more complicated than that of men. The perception towards female education had for centuries been unchanged because they were totally denied to any level of education. Earlier it was believed that an educated woman will lose her companion soon in their life. William Adam's Report on the State of Education in Bengal stated that, "A superstitious feeling is alleged to exist in the majority of Hindu families, principally cherished by the women and not discouraged by the men, that a girl taught to read and write will soon after marriages become a widow (Forbes 33)".

In those days, most women were dependent on men in the family. Mainly domestic slavery was confined to females. Women felt that education plays a vital role and it became an important issue. But the situation changed because of the selfishness of British colonizers and the positive attitude of Indian men. Although their reasons and interests might have been different, they both realized the significance of bringing some changes in the condition of women. "The Hindu Widow Remarriage act" which was passed in 1856 on inheritance, adoption and divorce have enhanced women's status in India. The person behind this act was no undoubtedly Raja Ram Mohan Roy and Ishwar Chandra Vidhyasagar. Meanwhile the learned people and socialists have tried to learn the problems of women and they tried hard to help them to get their education particularly in Indian society.

In the $19^{\text {th }}$ century the reformers of progressive and orthodox groups supported Indian women and their education. They believed that the gaining knowledge will eliminate social evils from the society. The only way to gain knowledge is education. Realizing the fact, slowly Christian missionaries and British gave their support for the first girls' school. After a great struggle the Indian women started to get education from the Universities in 1885. Apart from the other fields women had started to exhibit their talents in the realm of literature too. In the beginning, many Indian women composed poetry and short stories in other languages. Then, slowly, they started in colonizers language too. As women were the best upholders of storytelling they started writing stories from Myths and Epics. Their immense contribution to English literature especially in the field of novel was appreciable and praise worthy. In the beginning, it was not a successful one because; women were less access to information and education than men.

In last twenty years there was an astonishing growth for Indian women writers in English. Their works were published in India and elsewhere. The women writers expressed their discomfort with the aristocrat class women and they showed how the ordinary women were trapped in the pit of child marriage, dowry, prohibitions on women's education and enforced widow hood. Indian women are not marginals though they are marginalized in some cases. But the tradition of writing in India is patriarchal. The women came to writing much after men. Hence, men's writings have become representative of human voice and problems. In the beginning women's writing had become marginal and symptomatic of female issues. Women in India, without doubt started writing from the margin. This is evident from the fact that, people never say woman dancer, woman painter, but they do say woman writer.

Boehmer in his "Colonial and Postcolonial Literature" stated that, "colonized women were, as it is called, doubly or triply marginalized. That is to say, they were disadvantaged on the grounds not only of gender but also of race, social class, and, in some cases, religion and caste" (Boehmer 224). The Indian women were marginalized not only by colonizers, but by their own men too. Many women writers had explored the subjects of women in their writings in order to create an identity for own in the world of men writers. The struggle for identity created a new image on women writers. Their contributions to English novel gave a very big success to them and people started recognizing their work and they gave a tremendous welcome to them. Not only in their field, they faced many challenges in home too for their survival. They expected supporters from outside for their self. This theme was found in Nayantara Sohgal's 'Rich like US' (1986). Other novels like 'Inside the Havel' (1977) by Rama Mehla pointed out the same issue of traditional Indian culture, particularly about girls' education. Gita Hariharan's 'Two thousand faces of Night' (1992) 
also described the same. It was about a protagonist's quest for her cultural rights. In fact, women today enjoying her rights, desires and meaningful place in the society, because of those struggles the women writers underwent in order to establish an identity.

The works of women writers had given an unmistakable edge in Indian literary works. They sensitively portrayed a world in which women had rich in substance. The writings of women made the readers to feel that the women are real flesh and blood protagonists who make them and look at them with awe within their relationships to their surroundings, their society, their men, their children and their families. The men writers were not ready to treat the writings of women as a medium for entertainment. They were not supposed to write their tales with intrigue and fantasy. India's constitutional set-up in 1950 assured the country that women were given equality and Indian women could feel proud of their motherland. The two tools of society, namely, socialization and conditioning have made women defenseless and hence women have no choice to make their individual preferences.

Cornelia Sorabji and Sarojini Naidu, who were prominent in public and associated with women's causes and politics during the last period of British rule, were also acclaimed for their writings in Britain and British India. Sorabji's books about traditional women portrayed about women who lived with purdah and their reflections on their life in Britain and India were received enthusiastically by colonizers and Indian journals. Sarojini took efforts to revive her poetry, and she succeeded and became a national icon. Naidu spoke of her sudden realization that she was a poet with "New irresistible, unutterable longings and sensations". These longings found expression in celebrations of woman and womanhood, as well as in poems in which the love for her country borders on reverence.

The history of women novelists in English started with Toru Dutt who died at the young age. She had a repectable and aristocrat ancestry. The Dutts were known for their literary writings and generous impulses. Her "Binaca" and "Le Journal de mademoiselle d'Arvers" were her two novels dealt with the autobiographical information of the novelist. Her characters were entirely of Indian love and affection, sincerity and purity, though the characters are Spanish and French. Her contribution to literature would have been a better one if she had lived longer. Her writings were the best example for cultural heritage, folklores, myths and legends.

After the Second World War writers like Kamala Markandaya and Ruth Prawer Jhabvala had created a new track in literature which gave a new vision to the writers of that period. Their works were considered as an eye opener for social injustice. The Indian English novelists had adopted the borrowed form to make it a fit vehicle to write about their society with its varied customs and traditions. In most of the novels, the Indian novelists were, trying to analyze human relationships, especially the fragile man-woman relationship. Indian society is rapidly changing and this affects the day to day life styles. Here in India, the family continues to be the foundation of society and a lot of Indian novels have the family as their subject. Indian English literature had reached its height over a period of time and it did not achieve in a day. It took many years and many well- known writers worked hard to bring it to present status. Later, with the passage of time English literature had undergone several changes in writing style. Women novelists had boldly incorporated the subject of female experiences in their works and it shaken the cultural and language patterns of Indian literature.

In the past, the freedoms of women writers were limited so their writings on women's experiences were enclosed within the domestic realm. The authentic presentation about contemporary India created an impressive feel among the readers and especially from men folk. Then they started writing about regional variations and the participation of women during India's struggle for independence. In last four decades, the image of women had undergone a drastic change. Women writers changed their writing patterns and they moved towards the conflicted female characters instead of self-sacrificing characters. In all their characters the readers could find the basic theme of searching for identity. The $20^{\text {th }}$ century women's writing brought a new light and it acted as a medicine for modernism and cultural dramas. Their writings were of latest burning issues related to women which were not a new one and had been existed in the society since long. The works of women writers were entertained the learned people and the publishers for easy money making. 
In fact, the publishers believed that the literature got a new survival because of this type of bold writing. The society had started listening to the demands of women and their needs. Thus the revival of literature and society came into existence because of these kinds of writings by women writers.

\section{WORK CITED}

[1] Loobma, Ania. Colonialism/ Postcolonialism. London: Routledge, 2005.

[2] Marjorie, Pryse. "Distelling Essences: Regionalism and Women's Culture Literary Realism 1870-1910 XXV: 1-15, 1993.

[3] Jung, Anees. Women's Writing in India: New Prespectives. Sarup \& Sons. P : 41, 2002.

[4] Kulke, Hermann and Rothermund, Dietmar. "A history of India". London: Routledge, 2004.

[5] Forbes, Geraldine. Women in Modern India. Cambridge: Cambridge University Press, 1999.

[6] Boehmer, Elleke. "Colonial and Postcolonial Literature". Oxford: Oxford Press, 1995.

\section{Web Sources}

[7] www.sahityasetu.co.in

[8] www.indianetzone.com 